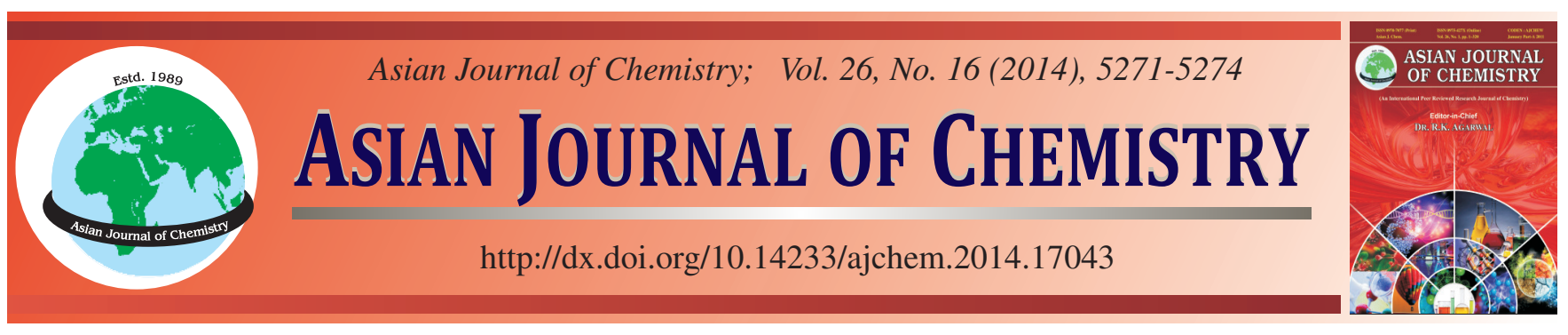

\title{
Determination of Arsenic Species in Underground Water by Capillary Electrophoresis-Inductively Coupled Plasma Mass Spectrometry
}

\author{
Na JiA ${ }^{1}$, Mei Han ${ }^{1}$, Guoxing ZhaO ${ }^{1}$, Lin Zhang ${ }^{1, *}$, Bingbing Liu ${ }^{1}$ and Yi $\mathrm{Li}^{2}$
}

${ }^{1}$ The Institute of Hydrogeology and Environmental Geology, Zhengding 050803, P.R. China

${ }^{2}$ Hebei Institute of Environmental Geological Exploration, Shijiazhuang 050000, P.R. China

*Corresponding author: E-mail: zh15369@163.com

Received: 16 January 2014;

Accepted: 21 March 2014;

Published online: 28 July 2014;

AJC-15676

\begin{abstract}
A method for the detection of trace As(III), As(V), monomethylarsonic acid, dimethylarsinic acid in underground water by capillary electrophoresis-inductively coupled plasma mass spectrometry (CE-ICP-MS) was developed. The optimized conditions of capillary electrophoresis including $\mathrm{pH}$ and concentration of the buffer, separation voltage and injection time were studied. The results showed that the above four species of arsenic were baseline separated within 9 min under the optimized conditions. The detection limits $(\mathrm{S} / \mathrm{N}=3)$ of As(III), As(V), dimethylarsinic acid, monomethylarsonic acid were $0.25-0.53 \mu \mathrm{g} / \mathrm{L}$ and the RSD $(\mathrm{n}=10)$ of the peak areas were smaller than $5 \%$. The method has been successfully applied to the determination of the species of arsenic in groundwater samples. The recoveries were 91-107\%. The method can be used for the speciation analysis of arsenic in real groundwater samples. The result indicated that $\mathrm{As}(\mathrm{III})$ and $\mathrm{As}(\mathrm{V})$ as the main arsenic speciations existed in groundwater of Nei Mongolia.
\end{abstract}

Keywords: Capillary electrophoresis, Inductively coupled plasma mass spectrometry (ICP-MS), Speciation analysis, Arsenic.

ᄂ _ - - - - - - - - - - - - - - - - - - - - - - - - - - - -

\section{INTRODUCTION}

Arsenic is a ubiquitous toxic metalloid element in the lithosphere, hydrosphere and biosphere ${ }^{1,2}$. In recent years, overexploitation of underground water has led to severe arsenic contamination of drinking water in India, Bangladesh, the United States, Argentina, China Taiwan and some other areas. About 36 million people has been threatened by arsenic contamination drinking in lives and health and it becomes a global problem $^{3}$. IARC, the U.S. Environmental protection agency (EPA) and the National Toxicology Program have put arsenic into human carcinogen list ${ }^{4}$.

Arsenic and arsenic compounds are extremely dangerous toxic and carcinogenic substances, however, the concentration of total arsenic is not an equitable way to show the impact of arsenic exposure levels, the environment and ecology. In general, inorganic arsenic is more toxic than organic arsenic, toxicity order: $\mathrm{AsH}_{3}>\mathrm{As}(\mathrm{III})>\mathrm{As}(\mathrm{V})>$ monomethylarsenic acid $>$ dimethyl arsenic acid ${ }^{5,7}$. Therefore, it was important to proceeding the quantitative and qualitative analysis of arsenic existing speciation.

Compared to LC and GC, capillary electrophoresis has higher separation efficiency and a relatively rapid separation ${ }^{8}$ and ICP-MS has the advantage in element detection and low detection limit ${ }^{9-11}$. Therefore, combined using of capillary electrophoresis and ICP-MS becomes a powerful analytical instrument for elements speciation analysis including arsenic. Since the first report of capillary electrophoresis and ICP-MS combined using by Olesik et al. ${ }^{12}$, this hyphenated technique has gained widely attention.

In this paper, we separate various forms of arsenic and arsenic compounds with the high sensitive inductively coupled plasma mass spectrometry to achieve the determination of arsenic species in water samples. This method offers a realatively rapid separation, high sensitivity, requires much smaller volume of sample and simple operating procedure, etc. ${ }^{13}$. The speciation characteristics of arsenic in waters, collected form undergroud water of Nei Morgolia in North China, has been studied by using capillary electrophoresis coupled with ICPMS (CE-ICP-MS). And get satisfactory spike results with standard substance.

\section{EXPERIMENTAL}

The standards of four species of arsenic including $\mathrm{AsO}_{3}{ }^{3-}$, $\mathrm{AsO}_{4}{ }^{3-}$, dimethylarsinic acid and monomethylarsonic acid were purchased from Narional Institute of Metrology China. All the stock standard solutions were stored at $4{ }^{\circ} \mathrm{C}$ and the running standard solutions were prepared by diluted stook standard solutions to the desired concentration with running buffer solution. The running buffer solution of $40 \mathrm{mmol} / \mathrm{L} \mathrm{H}_{3} \mathrm{BO}_{3}$ - 
$10 \mathrm{mmol} / \mathrm{L} \mathrm{Na}_{2} \mathrm{~B}_{4} \mathrm{O}_{7}(\mathrm{pH}=9.10)$ was prepared by dissolving analytical grade boric acid $\left(\mathrm{H}_{3} \mathrm{BO}_{3}\right)$ and sodium tetraborate $\left(\mathrm{Na}_{2} \mathrm{~B}_{4} \mathrm{O}_{7} \cdot 10 \mathrm{H}_{2} \mathrm{O}\right)$, which were purchased from TianJin BoHua Chemical Co. Lid., (TianJin, China), in Milli-Q water. In this experiment, water used is Milli-Q water (18.2 M $\Omega$ ) prepared by a Milli-Q equipment (Millipore, Bedford, USA) and the purity of argon gass is not less than $99.999 \%$.

Capillary electrophoresis-inductively coupled plasma mass spectrometry (CE-ICP-MS): The CE-ICP-MS system consists of an capillary electrophoresis system (Reeko instrument Co., Ltd.) and an Bruker 820-MS (Bruker Technologies, USA) which is equipped with a microconcentric nebulizer. The capillary electrophoresis system was fabricated with a $60 \mathrm{~cm}$ length $\times 75 \mu \mathrm{m}$ i.d $\times 375 \mu \mathrm{m}$ o.d., fused silica capillary and a high-voltage power supply which provided $-14 \mathrm{KV}$ voltage.

\section{RESULTS AND DISCUSSION}

Optimization of capillary electrophoresis conditions: Buffer solution including its chemical components, $\mathrm{pH}$ and concentration greatly affects the sepration of analytes by affecting the migration time of each analytes ${ }^{14,16}$. In order to obtain a better electrophoretic resolution, we optimized buffer solution under continuous sample-introduction mode with the similar manner reported earlier ${ }^{17,18}$. The experimental results showed that the mixture of boric acid and borate gave the most acceptable separation efficiency and reproducibility, therefore the mixed solution of boric acid and sodium tetraborate (4:1, mole concentration) was chosen as running buffer solution, which was used to seprated four species of arsenic [As(III), dimethylarsinic acid, monomethylarsonic acid, As(V)].

The $\mathrm{pH}$ of the running buffer solution strongly affects the electrophoretic resolution and sensitivity. The relationship between migration times/resolution and $\mathrm{pH}$ was studied with a $40 \mathrm{mM} \mathrm{H}_{3} \mathrm{BO}_{3}-10 \mathrm{mM} \mathrm{Na}_{2} \mathrm{~B}_{4} \mathrm{O}_{7}$ buffer solution in the $\mathrm{pH}$ range of 8.80-9.20. The results revealed in Fig. 1 that dimethylarsinic acid and monomethylarsonic acid could not be baseline separated when $\mathrm{pH}$ was lower than 9.05. However, when $\mathrm{pH}$ was higher than 9.20, the migration time of each peak was prolonged and finally resulted in increased noise and poor

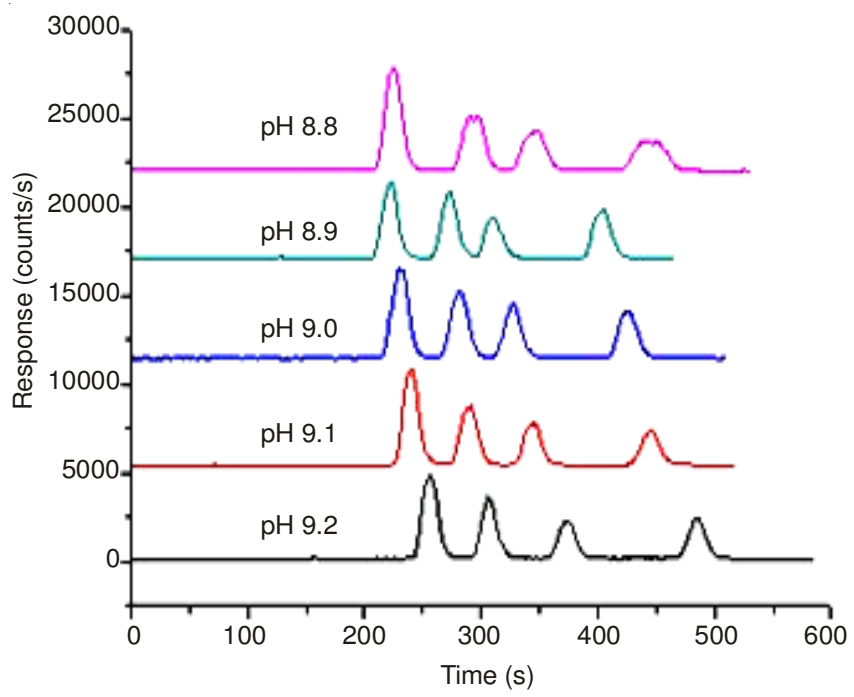

Fig. 1. Separation effect of different $\mathrm{pH}$ reproducibility. When the $\mathrm{pH}$ was about 9.10 , all four arsenic compounds were baseline separated with symmetrical peak shape. In this study, $\mathrm{pH}=9.10$ was selected as the optinum $\mathrm{pH}$ for the separation of As(III), dimethylarsinic acid, monomethylarsonic acid and $\mathrm{As}(\mathrm{V})$.

The effect of concentration of running buffer solution on the separation was also studied by using different concentrations of boric acid-borate buffer solution (boric acid: borate $=20: 5,30: 7.5,40: 10.0,50: 12.5$ and 60:15.0 mM) at pH 9.10. The results showed in Fig. 2 that the peak shapes and sensitivities of all four species of arsenic were improved and the migration times became longer with an increase in the concentration of running buffer solution. Considering both the analytical time and electrophoretic resolution, $40 \mathrm{mM}$ of $\mathrm{H}_{3} \mathrm{BO}_{3}-10$ $\mathrm{mM}$ of $\mathrm{Na}_{2} \mathrm{~B}_{4} \mathrm{O}_{7}(\mathrm{pH}=9.10)$ was selected as the running buffer solution.

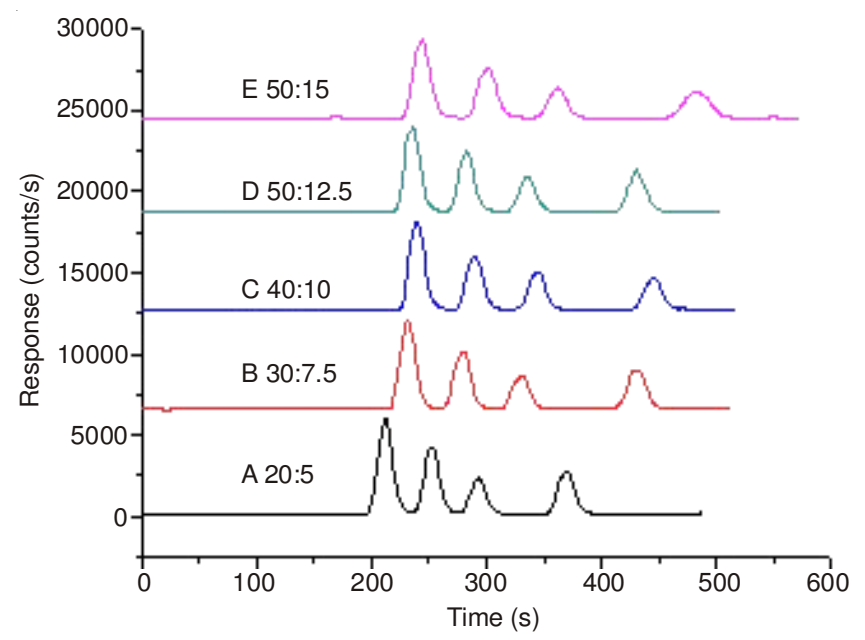

Fig. 2. Separation effect of different buffer concentration

Separation voltage optimization: The effect of the separation voltage on the migration time and electrophoretic resolution was investigated in the range of +10 to $+18 \mathrm{kV}$. The results showed that higher voltage was favourable to shorten migration time, that was obviously revealed in Fig. 3. However, high voltage led to the broadening of peak due to Joule heating effect. Considering the reproducibility and peak shapes, +14 $\mathrm{kV}$ was selected as the separation voltage. Different injection

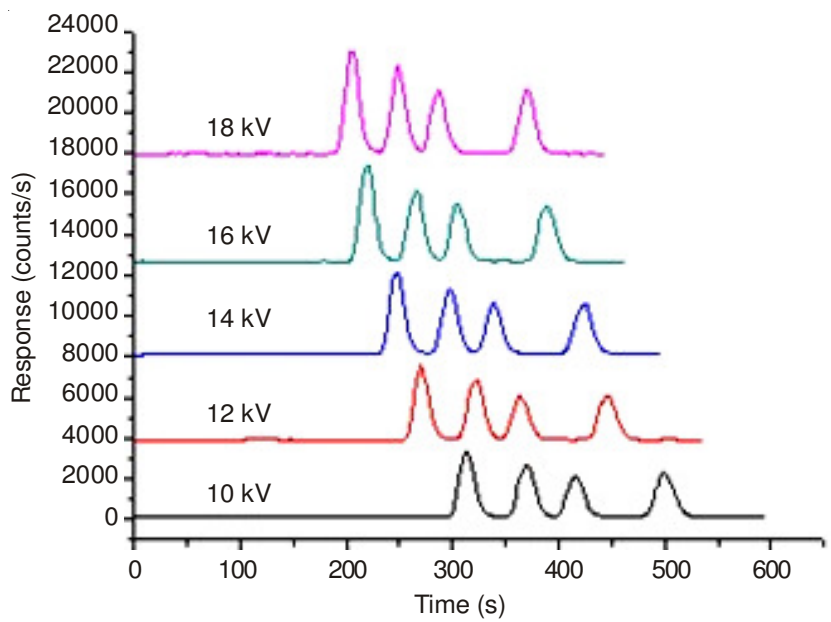

Fig. 3. Separation effect of different separation voltage 
times $(5 s-25 s)$ were tested in this experiment and results showed that the ICP-MS signal becomes higher with increasing injection time. However, longer injection time will reduce electrophoretic resolution. The results show that In the case of injector time is $15 \mathrm{~s}$, the pump speed is $14 \mu \mathrm{L} / \mathrm{min}$, achieved good separation effect, good peak shape, high sensitivity for four forms of arsenic compounds.

The optimum CE-ICP-MS conditions are shown in Table-1. Under the conditions of Table-1, all arsenical species in underground water were completely separated and determined by CE-ICP-MS. The electropherogram shown in Fig. 4.

\begin{tabular}{ll}
\multicolumn{2}{c}{ OPERATING CONDITIONS OF CE-ICP-MS } \\
\hline Parameter & Value \\
\hline CE voltage & $14 \mathrm{kV}$ \\
Injection time & $15 \mathrm{~s}$ \\
Buffer solution & $40 \mathrm{mM}$ of $\mathrm{H}_{3} \mathrm{BO}_{3}-10 \mathrm{mM}$ of $\mathrm{Na}_{2} \mathrm{~B}_{4} \mathrm{O}_{7}$ \\
& $(\mathrm{pH}=9.10)$ \\
Plasma flow & $18.0 \mathrm{~L} / \mathrm{min}$ \\
Auxiliary flow & $1.80 \mathrm{~L} / \mathrm{min}$ \\
Sheath gas & $0.18 \mathrm{~L} / \mathrm{min}$ \\
Nebulizer flow & $1.00 \mathrm{~L} / \mathrm{min}$ \\
Sampling depth & $6.5 \mathrm{~mm}$ \\
RF power & $1.4 \mathrm{KW}$ \\
First extraction lens & $-1 \mathrm{~V}$ \\
Second extraction lens & $-160 \mathrm{~V}$ \\
Third extraction lens & $-208 \mathrm{~V}$ \\
Corner lens & $-206 \mathrm{~V}$ \\
Skimmer gas source & $\mathrm{H}_{2}$ \\
Skimmer flow & $30 \mathrm{~mL} / \mathrm{min}$ \\
\hline
\end{tabular}

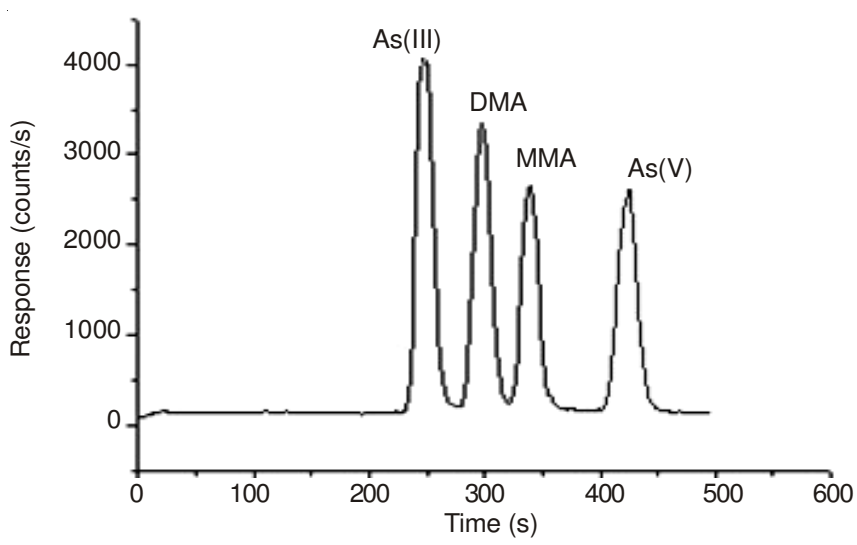

Fig. 4. CE-ICP-MS electropherogram of a mixed solution of As(III), As (V), dimethylarsinic acid and monomethylarsonic acid standards $(10 \mu \mathrm{g} / \mathrm{L})$

Parameter studies of CE-ICP-MS method: At above optimum conditions, four species of arsenic were baseline separated with in 9 min, under continuous sample-introduction mode. The same experiment was repeated for ten times and the RSD (relative standard deviation, $\mathrm{n}=10$ ) of peak areas was calculated to be a range of $1.96-4.85 \%$ for As(III) dimethylarsinic acid, monomethylarsonic acid and As(V) (Table-2). The detection limit (3s/s, the concentration necessary to yield a net signal equal to three times the standard deviation of the background) calculated with counts was $0.25,0.42,0.53$ and $0.46 \mu \mathrm{g} / \mathrm{L}$ for As(III) dimethylarsinic acid, monomethylarsonic acid and $\mathrm{As}(\mathrm{V})$, respectively.

\begin{tabular}{|c|c|c|c|c|c|c|}
\hline \multirow{3}{*}{ Comp. } & \multicolumn{6}{|c|}{$\begin{array}{c}\text { TABLE-2 } \\
\text { PRECISION OF THE METHOD }(\mathrm{n}=10)\end{array}$} \\
\hline & \multicolumn{2}{|c|}{$\begin{array}{l}\text { Low mass } \\
\text { concentration }\end{array}$} & \multicolumn{2}{|c|}{$\begin{array}{l}\text { Middle mass } \\
\text { concentration }\end{array}$} & \multicolumn{2}{|c|}{$\begin{array}{l}\text { High mass } \\
\text { concentration }\end{array}$} \\
\hline & $\begin{array}{c}\text { Detected } \\
(\mu \mathrm{g} / \mathrm{L})\end{array}$ & $\begin{array}{c}\mathrm{RSD} \\
(\%)\end{array}$ & $\begin{array}{c}\text { Detected } \\
(\mu \mathrm{g} / \mathrm{L})\end{array}$ & $\begin{array}{c}\text { RSD } \\
(\%)\end{array}$ & $\begin{array}{c}\text { Detected } \\
(\mu \mathrm{g} / \mathrm{L})\end{array}$ & $\begin{array}{l}\mathrm{RSD} \\
(\%)\end{array}$ \\
\hline $\mathrm{As}(\mathrm{III})$ & 10.0 & 2.72 & 20.0 & 1.87 & 50.0 & 2.09 \\
\hline DMA & 10.0 & 3.41 & 20.0 & 2.61 & 50.0 & 1.97 \\
\hline MMA & 10.0 & 4.05 & 20.0 & 2.03 & 50.0 & 2.35 \\
\hline $\operatorname{As}(\mathrm{V})$ & 10.0 & 4.85 & 20.0 & 2.12 & 50.0 & 1.96 \\
\hline
\end{tabular}

Adding three mixed standard solutions of low, medium and high mass concentration of arsenic compounds into a same sample, determine the three samples by the method we established and the recovery rates were shown in Table-3. By the results, in the case of different concentrations the recovery rates of $\mathrm{As}(\mathrm{III})$, dimethylarsinic acid, monomethylarsonic acid, As(V) are 97-102, 91-107, 93-103 and 96-102\%, respectively.

\begin{tabular}{ccccc}
\multicolumn{6}{c}{ TABLE-3 } \\
\multicolumn{5}{c}{ RECOVERIES OF FOUR ARSENIC SPECIATIONS FROM } \\
GROUNDWATER SAMPLE AT THREE SPIKED LEVELS \\
\hline Comp. & Original $(\mu \mathrm{g} / \mathrm{L})$ & Added $(\mu \mathrm{g} / \mathrm{L})$ & Found $(\mu \mathrm{g} / \mathrm{L})$ & $\mathrm{R}(\%)$ \\
\hline As(III) & 13.5 & $10,30,50$ & $23.3,42.6,64.5$ & $97-102$ \\
DMA & - & $10,30,50$ & $9.1,29.6,53.5$ & $91-107$ \\
MMA & - & $10,30,50$ & $9.3,28.2,51.7$ & $93-103$ \\
As(V) & 2.9 & $10,30,50$ & $13.1,31.5,51.6$ & $96-102$ \\
\hline
\end{tabular}

Determination of sample: Determine groundwater samples from Hohhot and Baotou for four forms of arsenic, the determine results are shown in Table-4. The results showed that the arsenic in groundwater in these regions are mainly $\mathrm{As}(\mathrm{III})$ and $\mathrm{As}(\mathrm{V})$. The sum of various forms of arsenic is almost equivalent to total arsenic compounds result, so the established method is reliable.

\begin{tabular}{ccccc}
\multicolumn{5}{c}{ TABLE-4 } \\
\multicolumn{5}{c}{ CONTENTS OF ARSENICS IN } \\
GROUNDWATER OF NEI MONGOLIA \\
\hline Samples & As(III) $\mu \mathrm{g} / \mathrm{L}$ & DMA $\mu \mathrm{g} / \mathrm{L}$ & MMA $\mu \mathrm{g} / \mathrm{L}$ & $\mathrm{As}(\mathrm{V}) \mu \mathrm{g} / \mathrm{L}$ \\
\hline 1 & 14.7 & - & - & 3.6 \\
2 & 235.1 & - & - & 52.6 \\
3 & 4.5 & - & - & 2.7 \\
4 & 1.2 & - & - & 0.2 \\
5 & 98.9 & - & - & 45.1 \\
6 & 78.4 & - & - & 26.8 \\
7 & 105.6 & - & - & 36.4 \\
8 & 23.2 & - & - & 2.9 \\
9 & 13.5 & - & - & 56.3 \\
10 & 1.6 & - & - & - \\
11 & 142.3 & - & - & \\
\hline
\end{tabular}

\section{Conclusion}

A method used to couple capillary electrophoresis with ICP-MS for determinated four arsenic species from underground water were developed in this study. Four forms of arsenic compounds [As(III), dimethylarsinic acid, monomethylarsonic acid and As(V)] are fully separated within 9 mins, the correlation coefficients are all above 0.9996 . The detection limit is $0.25-0.53 \mu \mathrm{g} / \mathrm{L}$ and RSD are less than $5 \%$. The recovery rates are $91-106 \%$. The results show that the method has advantages 
in good accuracy, high sensitivity, low sample consumption and short analysis time, it is suitable for determination of arsenic speciation in underground water. The predominant species of arsenic in water is inorganic arsenic such as As(III) and $\mathrm{As}(\mathrm{V})$, accounting for about $100 \%$ of total arsenic. The most toxic As(III) was detected in water samples, suggesting that water in few part was not safe for consumption.

\section{ACKNOWLEDGEMENTS}

The work is supported by the Fundamental Research Funds for the Institute of Hydrogeology and Environmental Geology (No. SK201205, No. SK201406).

\section{REFERENCES}

1. W.R. Cullen and K.J. Reimer, Chem. Rev., 89, 713 (1989).

2. M.F. Hughes, Toxicol. Lett., 133, 1 (2002).

3. D.K. Nordstrom, Science, 296, 2143 (2002).

4. W. Li, C. Wei, C. Zhang, M. Van Hulle, R. Cornelis and X. Zhang, Food Chem. Toxicol., 41, 1103 (2003).
5. S. Uleckiene, J. Didziapetriene, L. Griciute and D. Sukeliene, Studies of Trace Elements and Health, 22, 33 (2005).

6. J. Zhang, X. Liu and L. Jiang, Rock Miner. Anal., 37, 179 (2008).

7. Z.W. Di Chang, Foreign Med. Sci., 33, 121 (2006).

8. Z. Zhou, M. Li and Y. Bai, Chinese J. Chromatogr., 27, 598 (2009).

9. Y.F. Wang, Y.Z. Shi, H. Zhang, Y.-H. Chen; J. Lau, S. Wilbur and L. Ping, Spectrosc. Spectr. Anal., 10, 191 (2008).

10. L.L. Lv, Y. Xu, P. Yi, N. Qiu and X.-R. Gu, Spectrosc. Spectr. Anal., 3, 548 (2006).

11. X.Z. Cheng, C. Jin and K.C. Zhang, Spectrosc. Spectr. Anal., 10, 2421 (2008).

12. J.W. Olesik, J.A. Kinzer and S.V. Olesik, Anal. Chem., 67, 1 (1995).

13. J. Kang, T. Duan and J. Liu et al., Anal. Chem., 31, 1385 (2003) (in Chinese).

14. Y. Feng, Modern Instrumental Analysis and Practical Tutorial, The Peking University Publishing House, Beijing, pp. 61-75 (2008).

15. Y. Zhao, J. Zheng, L. Fang, Q. Lin, Y.N. Wu, Z.M. Xue and F.F. Fu, Talanta, 89, 280 (2012).

16. G.D. Yang, J.P. Zheng, L. Chen, Q. Lin, Y.Q. Zhao, Y.N. Wu and F.F. Fu, Food Chem., 132, 1480 (2012).

17. G. Yang, J. Zheng and H. Huang et al., Anal. Chem., 37, 532 (2009) (in Chinese).

18. Y. Zhao, J. Zheng, M. Yang and F. Fu, Chinese J. Chromatogr., 29, 111 (2011). 